UDC 577

\title{
Amazing MSC - phenomenology, problems, solutions and opportunities
}

\author{
V. A. Kordium, D. M. Irodov \\ Institute of Molecular Biology and Genetics, NAS of Ukraine \\ 150, Akademika Zabolotnoho Str., Kyiv, Ukraine, 03680
}

\begin{abstract}
The history of prediction and discovery of stem cells is briefly described in the article. The analysis of changes in ideas about the nature, functions, and status of mesenchymal stem cells (MSCs) in the organism, based on the data of the studies on MSCs published at different times, is presented. A hypothesis about MSCs as transient states of different cells was formulated. According to their functions the cells provide the reparation of the tissues (by programmed replacement of the dying or dead cells), and specialized differentiated cells (the induction of their renewal from various types of unauthorized damages, the renewal is induced by action of the sets of different signal molecules). MSCs participation in the cell cyclic-continuous renewal of an organism is being proposed as a new additional function of MSCs.
\end{abstract}

The ever-accelerating development of science has triggered some current fundamental changes in the pivotal notions of biology. In fact, a qualitatively new picture of the living is being built now. One of these ever-changing cardinal theoretical views (and their practical implementation) is the notion, associated with the term of "stem cells". Prior to this, for a century and a half, there have been some quiet and imperceptible "current" changes in the notions, based on actual, yet far from immediately acceptable and unusual, experimental data, unobvious application solutions, multifold changing ideas, new concepts, etc. The whole history of stem cells and the course of the development of this trend has been presented and analyzed in fine detail in scientific literature[1-3].

The onset of the notions which mark the beginning of "stem cells" is related to the histologist from Saint-Petersburg, Alexandr Alexandrovich Maximov, who, early in the previous century, voiced his opinion that during the person's lifetime blood corpuscles should be constantly formed somewhere, in some continuously existing source, and this source should be self-supported. Indeed, this idea was actually voiced by A. Maximov at the conference of hematologists in Berlin in 1909. However, the origins lie much deeper

(C) 2017 V. A. Kordium et al.; Published by the Institute of Molecular Biology and Genetics, NAS of Ukraine on behalf of Biopolymers and Cell. This is an Open Access article distributed under the terms of the Creative Commons Attribution License (http://creativecommons.org/licenses/by/4.0/), which permits unrestricted reuse, distribution, and reproduction in any medium, provided the original work is properly cited 
and have a larger scale. A new term "Stammzellen" ("stem cells" in German) and the pivotal notions about its meaning were first suggested and formulated as far back as in 1868 by E. Haeckel. Relating it to the embryonic development, he indirectly determined something, now called "embryonic stem cells". However, the understanding of the fact that some initial "stem" cell is in the core of the organism development is more than obvious, and the idea of "stem cells" and "stemness" (without naming these very terms) had previously been mentioned by R. Virchow and A. Weismann The term itself was introduced into scientific terminology by embryologists T. Boveri and V. Haecker in 1892. Thanks to these researchers, it became commonly used and universal. As for hematopoietic stem cells, the fact of their existence in terms of blood, their function and functioning principles were developed in detail, even using the term "stem cells" by A. Pappenheim in 1896. His map, suggested for the origin of blood cells of different types from the stem blood according to the stages of their formation and their schemes of images, is generally similar to the one, presented in textbooks and reviews nowadays both in principle and in many details. As for non-hematopoietic cells, their presence in bone marrow was discovered and described by J. Cohnheim in 1867 [4]. After wording and substantiating the idea of "stem cells" as some universal phenomenon, voiced in late century before last, there was some very slow motion towards studying them. The ideas and notions about stem cells were then related only to the fundamental sphere of mainly descriptive biology. Human biotechnology did not exist even in fantasies at the time, and the interest to stem cells was only in purely theoretical, descriptive and cognitive terms. Later, as the techniques of researches were developing, there started gradually increasing interest to them, which has now got its implementation in one of the strategic directions of biology and medicine.

"Real" stem cells (SCs) in all the completeness of properties, the actual "stem", out which "everything" can originate, are pluripotent cells, obtained from the blastocyst. But the most intense works are being conducted with $\mathrm{SCs}$, existing in the organism in the postnatal period.

It has long been believed that during the postnatal period the only "stem" (or at least the principal) cells in mammals were the ones, located in bone marrow. This notion was based on the opinion that these cells form "everything" there is in an adult organism - both blood corpuscles and, as required, the differentiated cells of solid tissues. It turned out later that all the organs have "their own" stem cells. They were called "regional cells", and according to their origin - constantly being fed from the "main reservoir" - hematopoietic SCs of bone marrow $[5,6]$. But an evident contradiction to this notion occurred pretty soon. Although SCs of bone marrow can get differentiated "into everything", however, the actual replacement via differentiation into the specialized cells of specific tissues and organs can frequently (or even as a rule) occur in the organism at the expense of "regional" stem cells [7]. It turned out later that "regional" SCs carry absolutely not the markers, which they should have had, if they had originated from the hematopoietic cells. Further studies started revealing even more differences between different SCs. It was obviously demonstrated in 
the functional way. For instance, the introduction of SCs of bone marrow into the brain or an eye promotes the repair of the damage. However, these SCs do not transform into neurons or retina in vivo. At the same time, their own "regional" cells do. During systemic introduction (in the course of a research or therapeutic procedures), they get accumulated in the lungs and eliminated quickly, and when the hematopoietic SCs of bone marrow are introduced into the lesion, after a short period the introduced cells are either not found at all, or rare remaining donor cells are registered [8]. But in fact it has been proven using the whole methodological armor that the hematopoietic SCs of bone marrow can actually transform into "everything". At least there are very many of such in vitro works which have been independently conducted in different centers, institutes, and laboratories.

Quickly accumulating experimental material and changing notions have brought about the change in priorities. In $1966 \mathrm{~A}$. Friendestein $[9,10]$ described fibroblast-like cells, growing in culture from bone marrow. At first, they were attributed the properties of stroma, where "actual" stem cells (the hematopoietic ones) exist in bone marrow, therefore these were called "mesenchymal stromal cells" - MSCi. It turned out later that these stromal cells were capable of getting differentiated into other types of cells. While they were identified only with the niches for "actual" SCs in bone marrow, the "stroma nature" seemed obvious. And, taking into consideration their intraosseous localization, even their ability to get differentiated, which is brought down to the classic triad even now - into bone tissue (osteoblasts), into cartilage (chondrocytes) and "fat reserves" (adipocytes) [11], looked quite logical. So the name of these cells was slightly changed, they were then called "mesenchymal multipotent stromal cells". But the deeper this "stroma nature" was studied as a phenomenon, the better the dynamics of the actual state of SCs, the processes in them, their markers, structures, functions, and other specificities were investigated, the more questions presented themselves. Some time later, it became clear that the regional SCs did not derive from the hematopoietic ones, they were a special complicated and heterogeneous system of populations [12]. And the "stromal" cells of bone marrow were only its first example, known to science, some "pilot sample". In terms of their nature they were all of mesenchymal origin. So they were called "mesenchymal" cells. And they were all united according to one general, main criterion of stemness, the ability to get differentiated into other, specialized cells.

But further improvement of investigations of fine mechanisms, processes, and states have stimulated the issues about the nature, origin, functions and location in the organism, cells, united only by the general criterion of "stemness" to require a new level of theoretical generalizations about what is to be defined by the term "stem cells". Such a generalization does not exist yet. But the problem of "stem cells" has actually been raised full-scale, as there is a need for some general concept without any inner contradictions, uniting something that is viewed as embryonic stem cells now, fetal stem cells, hematopoietic stem cells, "stem cells of bone marrow", regional stem cells, multipotent cells, mesenchymal stem/stromal cells, progenitors, committed cells, etc. 
For some time it was enough to have some general ideas, according to which SCs as such were somehow formed in the process of embryogenesis. Having been formed, "immediately", since the first days after birth they start and during subsequent weeks, months, years continue functioning "adequately". And surely "their own" SCs, located in different tissues, are the closest one to fulfill the "stem" tasks in "their" tissues (organs) [1, 13]. These notions may be called "the concept of cells with fixed stemness". These notions looked quite persuasive. Everything would have been fine, if it were not for new and new emerging and quite unusual experimental data about the processes, occurring in SCs and in their state, in terms of time. These demonstrated that there is some "current multidifferentiation", according to which one predecessor may be the origin of something, absolutely not corresponding to quiet notions of stable stemness. One of the examples may be found in the data about originating from peripheral nerve-associated gliathe cells of a tooth, and in the fact that glial cells make their contribution into the regeneration of teeth [14]. Such observations could still have been coordinated by references to continuing ontogenesis. After all, such transformations are temporary, terminal, and, as much as they are unusual, they are specific in their targeted predetermination.

However, a recent decade and a half have witnessed the accumulation of materials, evidently demonstrating overall and almost alltissue transitoriness of stemness. By that time, such transitoriness in the form of epithelialmesenchymal transitions (EMT) was described for embryogenesis [15, 16]. For embryogenesis, with its rapid comprehensive transforma- tion, growth, differentiation, etc., the transformations of the epithelial cells into mesenchymal ones and vice versa - (mesenchymal-epithelial transitions - MET), seemed to be quite logical. But then there came and still continues rapid accumulation of the experimental results, testifying to the fact that EMTs take place in the postnatal period as well. During the mentioned period this very process is bilateral too - in addition to EMTs, there are reverse transformations - mesenchymal-epithelial transitions, when the mesenchymal component gets formed from the epithelium and then fulfills stem functions, getting transformed into the specialized cells of the epithelial line [1619]. Such transitions are the implementation of something, inherent to embryogenesis, with its almost unlimited and universal multipotency, in the organism after birth. But during the postnatal period (and only then) there comes an additional source (and, thus, the mechanism) of stemness. There is a described (and studied in rather fine detail) special subpopulation of monocytes - monocyte-derived multipotential cells (MOMC), the cells of which are capable of getting differentiated in vivo into specialized cells of the mesenchymal line [20]. And here the notions about the independent status of different types of stem cells lose their definiteness, which was used as the basis for the whole theory of "stem cells". But, actually, complete indefiniteness was brought into the notions about SCs by the accumulation of experimental material, related to "stemness", "multi-" and some other "-potency" due to the attempts of answering some firstly very quiet, simple, and absolutely natural questions about the connection between something, occurring in the laboratory in vitro while cultivat- 
ing the cells "in a test-tube", and its status, state (or, more precisely - the state of the same ones) prior to the isolation from the organism, i.e. in the very organism - in vivo, in natural conditions, "actually". These questions were related to all the stem cells, but the problem was most urgent during the fundamental study and application of the cell fractions, most frequently defined as "mesenchymal stem/stromal cells" in the literature. "Everything is clear" with them in culture - these are cells with minimal mandatory set of markers, fibroblastlike in their form, capable of differentiating into specialized cells ( similar to the standard into chondrocytes, osteoblasts, adipocytes) [11]. According to these criteria, the isolation of MSCs from different tissues of different mammals into culture gave similar reproducible results. Except that they were not found in the organism proper. And those unique publications, describing such things, raised so many questions that it was preferred not to discuss the results obtained. Still, the experimental material got accumulated, albeit slowly. And today, in the framework of some not common theory yet, but a concept with no experimentally grounded contradictions, these cells (MSCs) are described in the form of some state, common for a wide population of cells, forming the endothelium of vessels. The main source of MSCs in the endothelium is believed to be pericytes. Sometimes they are even equated, assuming that all MSCs are actually pericytes. As for the abovementioned "all", this is just some emotional estimate of the authors of such assumptions. However, the omnipresence of pericytes and their transformation into MSCs do not cast any doubts. And the essence of pericytes in their "pericyte" status and distribution is all-organism-like, "Pericytes, also referred to as periendothelial cells or Rouget cells, are mural cells that lie on the abluminal side of blood vessels, immediately opposed to endothelial cells... Specialized pericytes called Ito cells, hepatic stellate cells, or hepatic lipocytes exist in the liver... ...another specific pericyte, the mesangial cell, is found in the kidney glomerulus... In bone marrow, cells exhibiting perycitic characteristics are referred to as adventitial reticular cells (ARCs) or myoid cells, as they express alpha-smooth muscle actin..." [13].

In addition to "pericyte-derivative" MSCs, there are also "non-pericyte-like" MSCs [22].

But it turned out later that there are also some "pericyte-like" cells, forming MSCs, and smooth muscle cells transform into MSCs, etc. Actually, almost all the endothelium cells (and the ones, interacting with them) can change into the MSC status. And as vessels permeate all the tissues and organs (except for cartilages, bones, nails, some other very specialized formations like the lens of the eye), practically the whole organism is just highly charged with the variety of something, even recently considered to be a special type of cells, localized in some special "niches" [13, 22, 23]. These mutual transitions change the essence of the notion of "stem cells" and it is very clearly determined in the characteristic, given to them now: "...thus, blood vessel walls harbor a reserve of progenitor cells, which may be integral to the origin of the elusive MSCs and other related adult stem cells." [23] The change in the notions sounds absolutely obviously, even in a provocative and demonstrative way, in the very terminology: "elusive MSCs", "a reserve of progenitor cells", which may be 
integral to the origin of MSC (progenitors of stem cells!), etc. It is not SC which is the key pillar of everything, but something "non-stem", something, forming SC, which then fulfills these "stem" functions after being formed. To get a full picture of this "stem-multi-mix", the fraction of blood monocytes, capable of becoming "stem-multi-whatever-is needed" is placed in the structure of vascular endothelium [20]. And it is absolutely universal and unusual for all the modern notions to publish the experimental data, described in fine detail and strictly registered in documents, about brain glial cells generating multipotent mesenchymal cells [14], the cells of vascular adventiata forming neurons and being the potential source of neuronal progenitors during post-ischemic restoration of hippocampus [24], the cells of blood vessels (pericytes) of brain with the potential of neural stem cells [25], etc. Due to their omnipresence, conditioned by perivascular localization, their restoring effect on local injuries is "instant" and omnipresent, and due to their inherent properties - it is potentially unlimited. Thus, this is how they are being viewed, "...MSCs may serve as siteregulated "drugstores" in vivo" [26].

As seen in the abovementioned experimental materials, described in the literature, MSCs are formed not only from pericytes, but also from other cells, localized in (and forming) internal walls of vessels. In addition, the formation of MSCs from special populations of white blood cells was described. But fibroblasts/myofibroblasts in different tissues may also originate from $\mathrm{CD}_{3} 4^{+}$of bone marrow and some "actual" stem mesenchymal cells, localized in bone marrow, colonizing/inhabiting the tissues "from afar" [21]. The "traces" of such origin (or overlapping) have been experimentally discovered. For instance, MSCs of adipose tissue (which are MSCs according to all the parameters) have a typical marker of hematopoietic $\mathrm{SC}-\mathrm{CD} 34^{+}$[27]. In their turn, fibroblasts, which originated from mesenchymal cells, were also found to be capable of multidifferentiation [4]. When the "classic" MSCs, isolated from the local site of the organism were cloned, it turned out that the colonies, obtained from the individual cells of such initial material differed among themselves when being titrated by markers. The heterogeneity, defined in an experimental way, demonstrated that the cells in the given local sample, which are "typical" MSCs according to common notions, are non-"characteristic", onetype for each tissue (organ), populations of MSCs, but rather their heterogeneous sets. However, according to their cultural properties, morphology, structure and other signs during their introduction into culture (in the very first inoculation, i.e. zero passage) they looked like a uniform homogeneous population [4].

On average $1 \mathrm{MSC}$ is per 18,000 mononuclear cells in human bone marrow $(1 / 18,000)$. $1 \mathrm{ml}$ of bone marrow content has $\approx 65^{\prime} 106$ mononuclear cells. Thus, $1 \mathrm{ml}$ of bone marrow contains only 3,555 MSCs (according to Muscler). But this is immediate determination. In terms of human treatment, the number of MSCs in the bone marrow aspirations for laboratory analyses via inoculations is estimated in the framework of therapeutic doses - hundreds of millions per injection. So, if the cells are not similar to MSCs, described by their morphology, in vivo, they might acquire their (that of MSCs) phenotype "immediately" after being attached to plastic in culture. And then 
they openly write that different cells, inoculated on plastic/glass in culture grow seemingly identical. Currently MSCs are defined as a phenomenon, conditioned by in vitro cultivation conditions [28]. If the available experimental data are generalized, they testify to the fact that MSCs are not just a special type of cells, or a population of different "stem" cells, but a transient state of different cells of mesenchymal origin (and not always, at that). For a researcher, they are unified by their identical growth in culture. They are "one-type" for an experimentalist, but everything looks different for the organism. It is different because these cells have to fulfill restoring functions. As for restoring functions, they may be fulfilled both in the form of classic stemness - the ability to get differentiated into different specialized cells, and in the form of release, exit, synthesis of signaling molecules, structural formation therein, etc., ensuring the safety of damaged highly specialized cells of organs and tissues.

But the notion of different- or one-type MSCs is further complicated by some special phenomenon - MSC polarization. Having occurred "as required", MSCs are further polarized "as required for the task". Two types of "one-type" (by their origin and main markers) MSCs have been described. The first type is remarkable for the reconstruction of metabolism for maximal biosynthesis (and further release into damaged tissues) of signaling, trophic, structural macromolecules. The task of these MSCs is to support the survival of damaged tissues; to remove the formed products of damaged cells, to stimulate the restoration of damages. In MSCs of the second type (polarization), metabolism is tuned to the differentiation with the purpose of replacing dead cells and spatial- structural restoring of tissue [29]. It is impossible to ensure it all using one constitutive status of one type of cells. Thus, statuses, types and origin of MSCs are highly heterogeneous. In the organism, MSCs are a multitransient state, occurring in the tissues from different cells of these tissues "as required". Immediate determinations demonstrate that in addition to the abovementioned, there actually is some small constitutive population in bone marrow, but not a "stromal" mesenchymal population, rather, the same basic "stem" one, like hematopoietic stem cells. These are two types of "actual" stem cells. The rest of cells in the organism are "stem-transient" when required, or "laboratory-stem" ones in culture, on plastic or glass according to the researcher's technology.

But the problem of "stem cells" does not end here. Additional mutual indefiniteness was brought in by some indications to the fact that MSCs in the organism are of different origin. Some MSCs originate from primary predecessors of blood cells, some - from "whereverpossible" due to EMT, and some - in the form of a special population of cells - originate as far as in early embryogenesis, and, further enduring multiple transformations, pass into the postnatal period of existence in the composition of tissues. And nobody has managed to even guess which function these classes of MSCs, different in their initial origin, have to fulfill. But as for culture, either on plastic or on glass, in the medium with fetal calf serum, they are so alike that all of them are still named the same - MSCs - even today. "To radically solve all the problems" - not to humor anybody, but absolutely seriously - there came a suggestion to call them all Medicinal Signaling Cells (MSCs) [30]. 
The next problem of SC problematics is their basic duality. The "real" stem cells are self-renewable cells and stem cells at the same time. The problem of stemness of SC has been discussed above.

Coming from the "very-very" principal property of SC as such, which conditions the existence of the stem cells proper, their selfreproduction should be defined by the property, preserving them, - self-renewal. But the experimental data demonstrate that "self-renewal" is not the monopoly of only one special population of cells. It seems like self-renewal in the organism is presented much more frequently than stemness.

It was determined that the property of selfrenewal is inherent to other cells, which have already been differentiated. This self-renewal occurs without any de-differentiation and subsequent differentiation into something different from them, into some specialized derivatives. The capability of self-renewal is inherent to differentiated cells proper. It has been described (and studied in the finest detail) for special populations of myeloid lineage, which stems not from SC of bone marrow, but independently from it, from yolk sac (YS). These are often equated with macrophages. They are Kupffer cells, Langerhans cells of skin, brain microglia and pleural macrophages [31]. They persist in the adult organism regardless of hematopoietic SCs. As of now, this is a property with unexplainable mechanisms - self-renewal for deeply differentiated cells, in this immediate differentiated status proper. This independence is absolute in terms of origin of these cells, "These results define a lineage of tissue macrophages that derive from the YS and are genetically distinct from HSC progeny" [32]. These are not even unipotent SCs, these are "self-renewable", differentiated and specialized, and "parallel-embryonic" cells by their origin, having soma, but being localized in soma. They originate not from the initial cells, composing soma, or the ones, which occurred in it, but from the cells, parallel to soma, - from yolk sac. Hepatocytes are self-renewable (and self-replaceable). One may assume that other "self..." cells will be discovered as well.

Therefore, the organism contains

- constitutional SCs with inherent stemness and self-renewal;

- transient stem cells;

- not stem, but constitutively self-renewable cells.

As for MSCs, their heterogeneity has already been mentioned above. It is especially obvious if scientific literature materials are brought together into the comparison format (Table 1).

And generally the existence of metazoans (humans included) is ensured not by constitutive SCs (though their role is fundamental), but rather by wide networks of differentiated cells, potentially having these properties.

All these are cells, capable of forming transient stemness "as required". These are all tissue macrophages, independently coming from the yolk sac. This is the embryo line (also autonomously from soma, originating from the yolk sac), which gives reproductive cells and, allegedly, many other types of cells, which potentially have the stemness property, not identified in them by science yet. As they are potentially stem cells, they might not even have SCs in the organism - they are their own $\mathrm{SC}$ "as required". Their renewal in the organism also occurs somehow. 
Summarized experimental data about "stem cells" and their transitoriness lead us to the new understanding of the cellular dynamics of the organism. Different types of cells have their potential of transition, formation, production of the transient status of MSCs. The "real" SCs (their classic variant being hematopoietic SCs of bone marrow) are "napping" according to their basic status and provided in rest with everything necessary for them by the surrounding niche cells. And MSC progenitors are con-

\section{Table 1. The variants of the diversity in}

mesenchymal stem cells and self-renewable cells

- Initially in soma layout (ectoderma and endoderma).

- The ones that were formed in the process of early embryogenesis in soma from neural crest initially as mesenchymal cells, which then passed from the embryo to postnatal tissues.

- The ones that are being formed during embryogenesis in different tissues of different organs due to epithelialmesenchymal transitions.

- The ones that are formed in the postnatal period due to epithelial-mesenchymal transitions.

- "Ephemeral" ones, like some transient state/derivative (also of mesenchymal origin) of "progenitors".

- Directly from "classic" hematopoietic stem cells.

- Via the chain of transitions from hematopoietic mononuclear cells into MSCs.

- The ones that were formed (as a continuous process or only in some special variants, which is not clear yet) with the properties of stemness as the main function of MSC, in the form of MSC2.

- The same, but with the main function of being signaling-regulating (with inhibited "stemness") in the form of MSC1.

- Stromal ones - with the function of "stroma", providing for differentiated, specialized and other cells, which may be as important as "stemness" proper, but has not been studied well yet.

- Specialized ones, which occur during embryogenesis, self-renewable and self-replaceable in the postnatal period without any stemness properties.

- "Parallel" ones from the yolk sac, self-renewable, but not "stem", specialized ones. stantly fulfilling their tissue "non-MSC" functions. Their potential of any transition to MSC is realized only "as required". As for the potential of different progenitors, it has different threshold of realization - in some it is highly sensitive to the necessity signals, in others it is overcome only in case of major traumas, requiring the mobilization of all the possibilities of the organism. But the nature of distribution for the most realized progenitors of MSCs (perivascular space of blood vessels) ensures actual saturation of all the organs and tissues with them - every time and everywhere. Even purely spatially, it provides the opportunity of replacing cells, dying according to the "schedule" (self-renewal of the organism), all the kinds of local micro injuries and damages. But the cells, replaced in such a way, are differentiated MSCs. There may be any differentiation - from very similar one (into fibroblasts) to extremely complicated one (into muscular or nervous cells). And now these cells, or the ones, capable of giving MSCs via EMT (not all the types, but many of them, wide-spread in the organism), become potential progenitors of MSCs - their new "wave". It changes the views about the cellular status of the organism. In the essence of this process, there is continuous cyclic "stem" transitoriness in the organism (Fig. 1). This transitoriness is not instantaneous, it does not happen for all the progenitors of all the organs and tissues at the same time. It is implemented differently in terms of space and time. But it goes on in all the tissues gradually and repeatedly. It is not instantaneous locally, but it is continuous integrally, in the scale of the whole organism as a unified entity. As the polarization of MSCs leads to the formation of cells with two types 


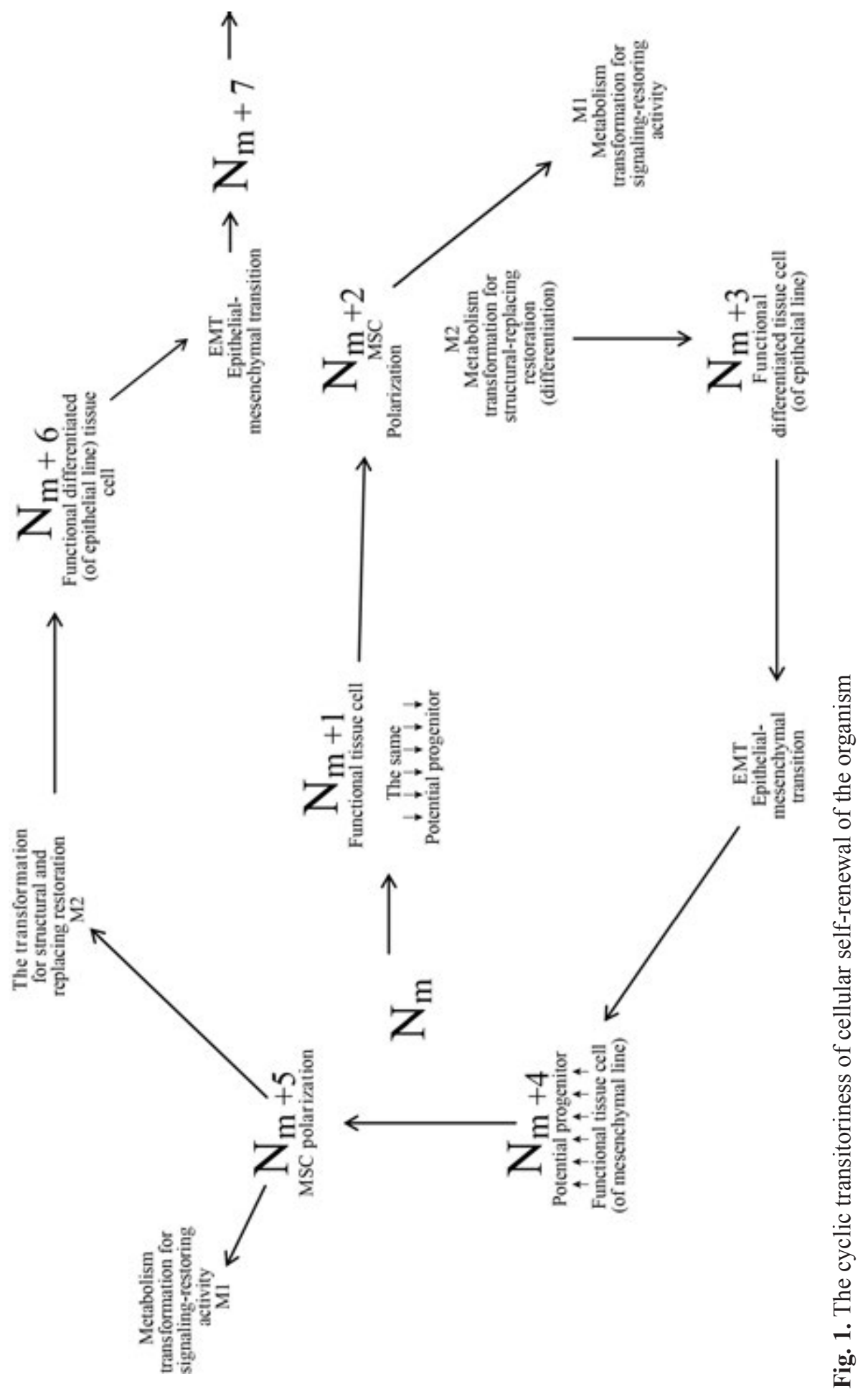


of self-renewal, the transient cyclic nature of MSCs ensures both replacement of the cells, which died "according to the schedule" and "not according to the schedule", and the maintenance, reparation of damaged and weak cells.

This massive cyclic nature may ensure the selection on a massive scale. Whatever has been burdened with mutations, will not pass the "check" for full value condition and fall out of the cyclicity. Actually, the check for full value condition is an absolutely necessary phenomenon to be fully complied with. During the embryogenesis of a female organism, an enormous number of ovum predecessors are formed. And almost all of them are destroyed. Quite a limited number of oocytes, which developed from them, come to the sexual maturity. A similar situation (although shifted in time and procedure) takes place during ontogenesis in the male organism, and leukosis should also be added here. The mechanisms of checking for full value condition are absolutely obscure now. However, the phenomenology of single cells passing into the reproductive cycle out of many millions of cells has been long determined. The same principal process - getting rid of inadequate ones - may ensure the cyclicity of MSCs in soma during the postnatal period. It is not as massive and radical, yet it is continuous. Cell replacement using MSCs, "checked" for full value condition, renewal of damaged ones, are, albeit currently hypothetical, yet already experimentally proven in many elements dually restoring (MSC1 and MSC2), polyfunctional, universal, and all-penetrating special system of preserving, maintaining the organism.

In actual life, it has that fantastically powerful and implemented potential of both stemness and self-support, ensuring the existence of highly organized metazoans for many years (and even hundreds of years, for some). As of now, only a very small amount out of this whole potential is known and used, but the possibilities of even this small amount are really impressive. The detailed study of this potential is the next stage of fundamental biology, which will open new horizons of practical implementation.

\section{REFERENCES}

1. Bianco P, Robey PG, Simmons PJ. Mesenchymal stem cells: revisiting history, concepts, and assays. Cell Stem Cell. 2008;2(4):313-9.

2. Brunt KR, Weisel RD, Li RK. Stem cells and regenerative medicine - future perspectives. Can J Physiol Pharmacol. 2012;90(3):327-35.

3. Maehle AH. Ambiguous cells: the emergence of the stem cell concept in the nineteenth and twentieth centuries. Notes Rec R Soc Lond. 2011;65(4):359-78.

4. de Girolamo L, Lucarelli E, Alessandri G, Avanzini MA, Bernardo ME, Biagi E, Brini AT, D'Amico G, Fagioli F, Ferrero I, Locatelli F, Maccario R, Marazzi M, Parolini $O$, Pessina A, Torre ML, Italian Mesenchymal Stem Cell Group. Mesenchymal stem/ stromal cells: a new "cells as drugs" paradigm. Efficacy and critical aspects in cell therapy. Curr Pharm Des. 2013;19(13):2459-73.

5. Jiang $Y$, Vaessen B, Lenvik $T$, Blackstad $M$, Reyes M, Verfaillie CM. Multipotent progenitor cells can be isolated from postnatal murine bone marrow, muscle, and brain. Exp Hematol. 2002; 30(8):896-904.

6. Poulsom R, Alison MR, Forbes SJ, Wright NA. Adult stem cell plasticity. J Pathol. 2002;197(4):441-56.

7. Boheler KR. Functional markers and the "homogeneity" of human mesenchymal stem cells. $J$ Physiol. 2004;554(Pt 3):592.

8. Leibacher J, Henschler R. Biodistribution, migration and homing of systemically applied mesenchymal stem/stromal cells. Stem Cell Res Ther. 2016;7:7. 
9. Friedenstein AJ, Petrakova KV, Kurolesova AI, Frolova GP. Heterotopic of bone marrow. Analysis of precursor cells for osteogenic and hematopoietic tissues. Transplantation. 1968;6(2):230-47.

10. Friedenstein AJ, Piatetzky-Shapiro II, Petrakova KV. Osteogenesis in transplants of bone marrow cells. J Embryol Exp Morphol. 1966;16(3):381-90.

11. Dominici M, Le Blanc K, Mueller I, Slaper-Cortenbach I, Marini F, Krause D, Deans R, Keating A, Prockop Dj, Horwitz E. Minimal criteria for defining multipotent mesenchymal stromal cells. The international society for cellular therapy position statement. Cytotherapy. 2006;8(4):315-7.

12. Klimczak A, Kozlowska U. Mesenchymal stromal cells and tissue-specific progenitor cells: their role in tissue homeostasis. Stem Cells Int. 2016;2016:4285215.

13. da Silva Meirelles L, Caplan AI, Nardi NB. In search of the in vivo identity of mesenchymal stem cells. Stem Cells. 2008;26(9):2287-99.

14. Kaukua N, Shahidi MK, Konstantinidou C, Dyachuk V, Kaucka M, Furlan A, An Z, Wang L, Hultman I, Ahrlund-Richter L, Blom H, Brismar H, Lopes NA, Pachnis V, Suter U, Clevers H, Thesleff I, Sharpe P, Ernfors P, Fried K, Adameyko I. Glial origin of mesenchymal stem cells in a tooth model system. Nature. 2014;513(7519):551-4.

15. Acloque H, Adams MS, Fishwick K, Bronner-Fraser $M$, Nieto $M A$. Epithelial-mesenchymal transitions: the importance of changing cell state in development and disease. J Clin Invest. 2009;119(6):1438-49.

16. Yoshida S, Kato T, Kato Y. EMT Involved in Migration of Stem/Progenitor Cells for Pituitary Development and Regeneration. J Clin Med. 2016;5(4). pii: E43.

17. Corallino $S$, Malabarba MG, Zobel M, Di Fiore PP, Scita G. Epithelial-to-Mesenchymal Plasticity Harnesses Endocytic Circuitries. Front Oncol. 2015;5:45.

18. Germani A, Foglio E, Capogrossi MC, Russo MA, Limana $F$. Generation of cardiac progenitor cells through epicardial to mesenchymal transition. $J \mathrm{Mol}$ Med (Berl). 2015;93(7):735-48.

19. Kalluri R. EMT: when epithelial cells decide to become mesenchymal-like cells. $J$ Clin Invest. 2009;119(6):1417-9.

20. Seta N, Okazaki Y, Miyazaki H, Kato T, Kuwana M. Platelet-derived stromal cell-derived factor-1 is required for the transformation of circulating monocytes into multipotential cells. PLoS One. 2013;8(9): e74246.

21. Ogawa M, LaRue AC, Drake CJ. Hematopoietic origin of fibroblasts/myofibroblasts: Its pathophysiologic implications. Blood. 2006;108(9):2893-6.

22. Feng J, Mantesso A, De Bari C, Nishiyama A, Sharpe PT. Dual origin of mesenchymal stem cells contributing to organ growth and repair. Proc Natl Acad Sci U S A. 2011;108(16):6503-8.

23. Crisan M, Yap S, Casteilla L, Chen CW, Corselli $M$, Park TS, Andriolo G, Sun B, Zheng B, Zhang L, Norotte C, Teng PN, Traas J, Schugar R, Deasy BM, Badylak S, Buhring HJ, Giacobino JP, Lazzari L, Huard J, Péault B. A perivascular origin for mesenchymal stem cells in multiple human organs. Cell Stem Cell. 2008;3(3):301-13.

24. Yamashima T, Tonchev AB, Vachkov IH, Popivanova BK, Seki T, Sawamoto K, Okano H. Vascular adventitia generates neuronal progenitors in the monkey hippocampus after ischemia. Hippocampus. 2004;14(7):861-75.

25. Dore-Duffy P, Katychev A, Wang X, Van Buren E. CNS microvascular pericytes exhibit multipotential stem cell activity. J Cereb Blood Flow Metab. 2006;26(5):613-24.

26. Caplan AI, Correa D. The MSC: an injury drugstore. Cell Stem Cell. 2011;9(1):11-5.

27. Hoogduijn MJ. Are mesenchymal stromal cells immune cells? Arthritis Res Ther. 2015;17:88.

28. Keating A. Mesenchymal stromal cells: new directions. Cell Stem Cell. 2012;10(6):709-16.

29. Wagner W, Feldmann RE Jr, Seckinger A, Maurer $M H$, Wein F, Blake J, Krause U, Kalenka A, Bürgers HF, Saffrich R, Wuchter P, Kuschinsky W, $H o A D$. The heterogeneity of human mesenchymal stem cell preparations--evidence from simultaneous analysis of proteomes and transcriptomes. Exp Hematol. 2006;34(4):536-48.

30. Caplan AI. What's in a name? Tissue Eng Part A. 2010;16(8):2415-7.

31. Hoeffel G, Wang Y, Greter M, See P, Teo P, Malleret $B$, Leboeuf $M$, Low D, Oller $G$, Almeida F, Choy SH, Grisotto M, Renia L, Conway SJ, Stanley ER, Chan JK, Ng LG, Samokhvalov IM, 
Merad M, Ginhoux F. Adult Langerhans cells derive predominantly from embryonic fetal liver monocytes with a minor contribution of yolk sac-derived macrophages. $J$ Exp Med. 2012;209(6):1167-81.

32. Schulz C, Gomez Perdiguero E, Chorro L, SzaboRogers H, Cagnard N, Kierdorf K, Prinz M, Wu B, Jacobsen SE, Pollard JW, Frampton J, Liu KJ, Geissmann $F$. A lineage of myeloid cells independent of Myb and hematopoietic stem cells. Science. 2012;336(6077):86-90.

\section{Дивовижні МСК - феноменологія, проблеми, рішення, можливості}

В. А. Кордюм, Д. М. Іродов

У статті коротко наведена історія передбачення і відкриття стовбурових клітин. На опублікованих в різні часи матеріалах $з$ досліджень МСК, розглядається зміна уявлень про їхню природу, функції та статус в організмі. Сформульовано припущення, що МСК є транзиторним станом різних клітин. Вони забезпечують репарацію як тканин (заміщаючи ті клітини що відимирають вчасно або випадково загиблі) так і високо диференційованих клітин (індукуючи в них відновлення наборами своїх сигнальних структурних молекул при різних несанкціонованих порушеннях). Припускається функція МСК у клітинному циклічно-безперервному оновленні організму, протягом усього життя.
К л ю ч о в і с л о в а: МСК, функції, оновлення, репарація.

\section{Удивительные МСК - феноменология, проблемы, решения, возможности}

В. А. Кордюм, Д. М. Иродов

В статье кратко приведена история предсказания и открытия стволовых клеток. На опубликованных в разное время материалах по изучению МСК, рассматривается смена представлений об их природе, функциях и статусе в организме.

Сформулировано предположение о том, что МСК представляют собой транзиторные состояния различных клеток. По своим функциям они обеспечивают репарацию тканей (замещая планово отмирающие и погибшие) и специализированных дифференцированных клеток (индуцируя в них наборами своих сигнальных структурных молекул восстановление при различного рода несанкционированных нарушениях). И как еще одна функция МСК, предполагается их участие в клеточном циклично-непрерывном обновлении организма, на протяжении всей жизни.

К л юч е в ы е с л ов а: МСК, функции, обновление, репарация.

Received 15.09.2016 